DOI 10.18699/SBB-2020-45

\title{
Филогенетическое разнообразие культур аноксигенных фототрофных бактерий из водоемов России
}

Бахмутова Е.*, Намсараев 3., Комова А.

НИЦ «Курчатовский институт», Москва, Россия

*e-mail: bahmutovaelizaveta@gmail.com

Ключевые слова: аноксигенные фототрофные бактерии, филогенетическое разнообразие

Мотивация и иель: Водоемы России обладают широким диапазоном физико-химических условий, и вследствие этого обитающие в них микробные сообщества характеризуются большим разнообразием. Цель данной работы - изучение филогенетического разнообразия культур аноксигенных фототрофных бактерий (АФБ), выделенных из водоемов России. АФБ могут быть использованы в биоремедиации, а также представляют интерес как потенциальные продуценты биополимеров, водорода и других промышленно важных веществ, поэтому эта работа очень актуальна.

Meтоды и алгоритмы: Объектами нашего исследования являются 20 культур АФБ, выделенных нашей научной группой из отобранных проб из 10 водоемов России. Из исследуемых культур АФБ была выделена ДНК, после чего 13 из полученных образцов использовались для проведения ПЦР на ген, кодирующий последовательность $16 \mathrm{~S}$ рРНК, с последующим секвенированием по Сэнгеру. Для остальных 7 образцов было проведено полногеномное секвенирование на приборе Illumina MiSeq. Последовательности генов $16 \mathrm{~S}$ рРНК исследуемых штаммов были выровнены против базы референсных последовательностей NCBI при помощи NCBI BLASTn. Было проведено множественное выравнивание с последовательностями отобранных ближайших родственных видов для каждого штамма, по результатам которого были построены филогенетические деревья.

Результаты: Согласно филогенетическому анализу, 15 из отобранных штаммов можно отнести к классу Alphaproteobacteria, 2 штамма относятся к классу Betaproteobacteria, 3 штамма относятся к классу Gammaproteobacteria. Были обнаружены штаммы, уровень сходства по последовательности $16 \mathrm{~S}$ рРНК и морфофизиологические характеристика которых позволяют отнести их к 2 новым родам и 4 новым видам в класcе Alphaproteobacteria. Были обнаружены штаммы, способные к аноксигенному фотосинтезу, в то время, как их ближайшие родственные виды являются хемотрофами.

Заключение и доступность: Был проведен филогенетический анализ 20 штаммов аноксигенных фототрофных бактерий, выделенных из проб воды из 10 водоемов России. Среди них были обнаружены потенциальные представители 2 новых родов и 4 новых видов.

Благодарности: Работа выполняется на основании Соглашения с Минобрнауки РФ № 075-15-20191659 от 31.10.2019. 